\title{
The First Forcing of the Khaibar Pass, 1838-39
}

\section{Major H. W. Pearse}

To cite this article: Major H. W. Pearse (1897) The First Forcing of the Khaibar Pass, 1838-39, Royal United Services Institution. Journal, 41:230, 497-505, DOI: 10.1080/03071849709416019

To link to this article: http://dx.doi.org/10.1080/03071849709416019

\section{曲 Published online: 11 Sep 2009.}

Submit your article to this journal $\pi$

Џll Article views: 4

Q View related articles $匚$ 


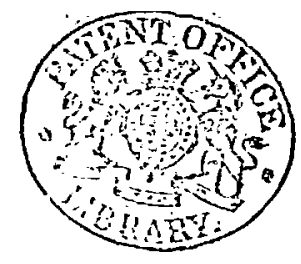

THE FIRST

\section{FORCING OF THE KHAIBAR PASS, 1838-39.}

By Major H. W. PEARSE, The East Surrey Regiment.

IN June, 1838, Mr. Macnaghten, ${ }^{1}$ Lord Auckland's foreign secretary, obtained from Ranjit Singh, the dying ruler of the Punjab, his signature to an engagement of close alliance, known subsequently as the "Tripartite Treaty:" This was practically a revival of the Treaty between Ranjit Singh and Shah Shuja, the exiled ruler of Afghanistan, with the addition of the British Government as a third party.

Shah Shuja, who had been for many years a resident in India, and a pensioner of the British Government, readily signed the treaty, by which he had everything to gain, and nothing (but his life) to lose, and the immediate result of the triple alliance was the invasion of Afghanistan.

The plan of campaign was as follows:-

The British Army and the contingent raised in India for Shah Shuje, and officered by Englishmen, were to proceed through Sind and enter Afghanistan by the Bolan and Khojak Passes. Little or no opposition was anticipated by Lord Auckland and his advisers, who l:ad pursuaded themselves that the restoration of Shah Shuja and the deposition of Dost Muhammad would be received with joy.

The share of the Sikh ruler, the third party to the Treaty, was, for obvious reasons, a limited one. Any invasion of Afghanistan by the hated Sikhs would have caused a bitter war of religion and revenge. It was, therefore, decided that Maharaja Ranjit Singh was to give the services of a contingent of Muhammadans, selected from every regiment in his army, and therefore a dificult body to weld into a serviceable shape. This contingent was to support a body of levies, to be formed from Afghans who might desert the standard of Dost NIuhammad.

Finally Ranjit Singh engaged to give moral support to the undertaking by moving the main body of his army to the neighbourhood of

1 This unfortunate official accompanied the British Arny to Kab:l, and was there assassinated by Dost Muhammad's son, Muhammad Abkar Khan, "the Wallace of Kabul." 
Peshawar, and by proceeding there in person to superintend the formation of the contingent.

The command of the combined northern force was conferred nominally on Prince Timur, the heir-apparent of Shah Shuja; but it was understood that all operations that might be undertaken would be directed by an English political officer, Colonel Claude Mirtins Wade.

Claude Wade, born in 1794, was the son of Colonel Joseph Wade, of the Bengal Army, and godson of the famous soldier of fortune, Claude Martins. He had had a long and varied experience of Indian service, having served continuously in that country from the year 1809 , when he started life as a cadet of fifteen. From the first, he showed exceptional talent and industry, and in February, 1823, was appointed "Political Assistant" at Ludhiana, "when he was brought into close contact with Shuja-ul-ilulk, the dethroned King of Afghanistan. From this period also, for no less than seventeen years, Wade had charge of the political relations between the British Government and Maharaja Ranjit Singh, the ruler of the Punjab, and obtainel great influence with that potentate.

The time had now come, however, for the sword to replace the pen, and for Wade to show himself a skilful organiser, and a bold and determined leader.

The first official intimation of the intended course of action of the force entrusted to him, dated July" 23rd, 1838, runs thus:- "Captain" Wade is informed that he is to be placed in charge of our relations on the side of Peshawar. . . . It is the wish of the Government that the - operations of the Shah's son should be confined in the first instance to gaining adherents to the cause of his father, and especially to conciliating the Khaibaris."

- It would be wearisome to trace minutely the development of crents, but. it may suffice to say that Lord Auckland's Government gradually cáme to the decision that Wade's demonstration on the Khaibar side should be converted into an actual attack, with the object of hampering: the defence of Dost Muhammad, and of prerenting him from advancing freely to meet the Army of the Indus.

Towards the end of October, 1838, Dr. Lord, one of Macnaghten's political assistants, was sent to Peshawar to establish relations with various chiefs, whose acquaintance had been made by ${ }^{-}$Sir Alexander Burnes during his travels. Lord, an enterprising traveller, a man of learning, and a gallant soldier, was furnished with letters from Burnes to these chicfs, and was attached to Wade's mission until it reached Kabul.

On December 20th, Wade was informed that "acquainted as he was, by frequent conferences with the Governor-General, of the views and opinions entertained by his lordship relative to the present position of affairs, it is not deemed necessary to furnish him with any detailed instructions for his guidance." He was to "make use of the Shahzada's presence in such mode as might seem to him best calculated to secure

1 He had been promoted Major on the 25 th June, 1835, but the Gazette had not arrived in India. 
adherents to the Royal cause." He was given absolute discretion ss to expenditure, though economy was enjoined on him.

Wade, who had been granted the rank of Licut.-Colonel from September 28th, 1838, arrived at Peshawar on the 11th March, 1839, and, a few days later reccived further instructions in the shape of observations by the Governor-General on an open despatch from Mr. Macnaghten. "You are advised, in case of Dost Muhammad leaving Kabul to engage the allied Army when advancing on the capital, to proceed yourself, with the Shahzada and all the Mussulman troops you can collect, against Kabul ; but his lordship is of opinion that, as the expecliency of a measure of this decided character must depend upon circumstances, the existence of which cannot be predicately calculated upon beforehand, no instructions can be given that will prove as safe a guide for your conduct as your own prudence and sagacity."

Much more to the same cffect follows, and on May 10th there is a similar letter pointing out the mischief that would be wrought by too much forwardness and also by undue caution. This letter concludes with an cxpression of Lord Auckland's hope that Coloncl Wade might be able to overcome the obstacles that were to be expected on the road from Peshawar to Kabul, and to reach the capital simultaneously with the Army of the Indus.

Meanwhile, Wade and his assistants had not been idle. From the moment of his arrival at Peshawar, where he found all the Sikh preparations hopelessly in arrears, he and they had displayed unceasing energy and boundless resource. Undeterred by obstructions and disappointments without number, undaunted by the sickness and exhanstion that follow prolonged exertion in the Peshawar Valley, they laboured from March to July at the task of forming and disciplining a force that would face and capture the hitherto virgin Khaibar.

The "Orders" issued daily by Wade still exist, and form an interesting record of the gradual growth and orgarisation of the force, while they also bear witness to his military capacity.

Wade was extremcly fortunate in regard to the officers who were detailed to assist him in his task. Of these, Dr. Lord has already been mentioned, and the after career of Mackeson, ${ }^{1}$ who was also employed in a political capacity, is well known.

The services of a very small body of Regular troops of the Bengal Army were granted to Wade's mission, and Captains Ferris and Farmer, Licutenants Cunningham, ${ }^{2}$ Maule, and Barr, who accompanied these troops, all did excellent service in various capacities.

Much of the credit of the successful attack on the Khaibar must be given to Mackeson, who carried out Wade's orders with admirable courage and determination, and performed feats that our subsequent experiences in that unhappy region prove to be truly extraordinary.

${ }^{1}$ Afterwards Colonel Frederick Mackeson, C.B., assassinated in 1853, when Commissioner of Peshawar.

'Joseph Davey Cunningham, son of Allan Cunningham, and historian of the Sikhs. His promising career came to an untimely end. 
Lieutenant Barr, the last-named officer of the mission, who belonged to the Bengal Artillery, published his diary under the title, "Journal of a March from Delhi to Peshawar, and from thence to Kabul," and in it gives a good idea of the materials upon which Colonel Wade and his assistants had to work.

"MIost of the mornings and evenings were occupied in admitting volunteers into the service of the Shahzada, and so many Durani horsemen presented themselves to be enrolled, that it became necessary to select those only whose steeds and arms were of better than ordinary description. Several chiefs, who came for this purpose, attended by their clansmen, were fine specimens of the rude and predatory soldier, their manly and tall figures being generally enveloped in the folds of a crimson " choga," embroidered with gold, which, opening in front, displayed a "kamarband," studded with pistols and knives, or an arm protected by a steel gauntlet, which reached to the elbow and was terminated at the hand by a flexible glove of chain rings."

On the 14th April, 1839, three days after the arrival of General Ventura', from leave of absence in Europe, a mutiny broke out in the "Najib" battalion, which but too clearly showed how weak was the discipline of the Maharaja's levies. This battalion was commanded by Colonel Jacob Thomas, son of the gallant adventurer George Thomas, who from being a sailor before the mast rose to become an independent sovereign. Jacob Thomas had not inherited the ability or strength of character of his father, and on this occasion his men turned him and his adjutant out of their camp, and declared they would have nothing more to do with either of them.

In the month of May, a battalion of Gurkhas also mutinied, because General Ventura had placed their adjutant under arrest. The adjutant being popular with them, they demanded his release, which the General refused. Sceing that he was prepared to meet force with force, the Gurkhas returned to their tents, which they presently struck, and, colours flying and band playing, marched out of camp. The iron hand of the old Lion of Lahore was relaxing, and the mutineers were allowed to remain at Peshawar and avoid the march to Kabul.

The fact is that all the Sikh troops had a great dread of campaigning in the Khaibar region. General Avitabile, at this time Governor of Peshawar, used to say that the word Khaibar gave the Sikhs cholera.

Of such material it was Wade's task to form a force sufficiently trustworthy for an advance into the dreaded Khaibar, there to meet on their own ground those of the warlike tribes who were unwilling or afraid to join the Royal cause.

As for the Afghan levies, but little training could be given them. In Wade's words:- "However desirable it might be to bring these levies into a tolerably efficient state of discipline, neither time nor the habits of the people admit of it. The officers in charge will, therefore, merely form

${ }^{1}$ General Ventura was an Italian officer, who had served Napoleon. He was one of Ranjit Singh's most trusted and faithful servants, and was deputed at this time by the dying Maharaja to represent him at Peshawar. 
them into ranks, two deep; teach them the facings and the manner of marching in column and forming line."

A letter from Cunningham, who acted as Wade's staff officer to his chief, relating to some correspondence with Captain Farmer, who at the time was in command of the camp, gives some insight into the management of the force, and also gives an amusing indication of the character of a brave but somewhat eccentric officer.

"My Dear Colonel, "June 4th, 1839.

"I wrote to Farmer about his parade-ground, mentioning, among other reasons for not beginning upon it, that you considered our stay here as uncertain. I said, in conclusion, that you would be glad if he could find an opportunity of moving the troops about a bit in the vicinity of the camp, in order that they might be the better fitted for any arduous service in the rugged and inhospitable hills before us-a style which precisely suits his 'Ercles vein.

"Sincerely yours,

"J. D. Cunninghans."

When the starched ideas of the period regarding drill and discipline are considered, it may be considered fortunate that an oflicer of Wade's stamp was selected for the command of a hastily-raised and organised force. He had been too long free from the bonds of red-tape to cling to the parade drill which ninety-nine men out of a hundred would in those day's have inflicted on the Sikh drafts and Afghan levies, and it was with such practical training as is indicated in Cunningham's letter that Wade and his eleven assistants occupied their time.

They may justly have contemplated with pride the result of their labours when, on July 19th, 1839, the order to advance was given by Wade to a small army numbering between nine and ten thousand men.

Their composition was is follows:-

Regular troops of the Bengal Army-strength, 380 ;

Sikh contingent (with ten guns)-strength, 5,000 to 6,000 ;

Afghan levies-strength, about 4,000.

Among the last named were included about 100 Multanis, brought with him from that province by Lieutenant Mackeson; and these men did more than their share of the fighting.

On the day of the advance, General Ventura, prevented by the intrigues which followed the death of Ranjit Singh from leaving Punjab, handed over command of the Sikh contingent to Colonel Shaik Basawan, who proved a brave and trustworthy, as well as a capable, commander; Ventura's aide-de-camp, a French officer, Captain August Lafont, becoming Staff officer for the contingent to Colonel Wade.

The diplomatic action of Wade and Lord had secured the neutrality of many of the tribes, and had contributed to prevent Abkar Khan from moving forward to Ali Masjid. This chief, the ablest and bravest of Dost Muhammad's sons, remained inactive at Jalalabad until, on July 
23ril, immediately after the fall of Ghuzni, he was recalled to Kabul by: his father.

Meanwhile, Wade was slowly but surcly advancing on Ali Masjid, the key of the Khaibar. On July 22nd a strong force, under his personal command, seized the heights about four miles from that fort, Caplain Ferris' regiment of Afghans guarding the flanks during the advance. At the same time, Mackeson, with his Miltanis and a party of Sikhs, made a converging march, but was attacked so ficrcely by the Afridis that the Sikhs fled, and the Multanis were sore pressed. .

Hastily throwing up a small breastwork, Mackeson maintained with difficulty the unequal contest, for the enemy outnumbered him greatly, and were, at least, equally well armed. Though reinforced by Captain Fẹris and his regiment, and eventually aided by Lieutenant Barr with a mortar, this force had a narrow escape from disaster. Ammunition ran short, and Ferris' levy became unstcady.

Among the letters and notes preserved by $W^{\prime}$ de $^{1}$ are two written very hastily in pencil, on this occasion, on rough "country paper"; the first runs thus:-

"MY DeAR WADE,

"I have just reccived your note. I will assist you as far as in my power; but the distance is, I fear, too great for my "Jezails" to reach the jarty on the oppesite side of the hill.

$$
\begin{aligned}
& \text { "Yours very truly, } \\
& \text { "F. NAACKESON." }
\end{aligned}
$$

The second note, written during the Afridi attack, runs :"MY DEAR WADE,

"I have sent for ammunition, but at present neither my own men nor Captain Lafont's men, the "Najibs," have any, nor have the Kohistanis; how are we to defend our post?.

$$
\text { "Yours, F. MI." }
$$

Eventually, Nackeson obtained reinforcements of men and ammunition from Wade's position, and he and Ferris were enabled to hold their ground.

To those acquainted with Afridi habits it will cause no surprise to learn that the baggage of the Mission and troops suffered considerably during the action, among the articles carried off being the Shahzada's throne (!) and one of Colonel Wade's large tents.

The 23rd July was employed by Wade in improving his position on the heights by moving further to the front in certain places, and in strengthening his communications. On the 24 th he advanced jet further.

\footnotetext{
1 There are several similar messages, sent during the operations; and those above are published, not because of any special value that they possess, but in the hope that among the readers of this Joursal there may be some who possess similar relics of more important campaigns. It is greatly to be hoped that such written orders, memoranda, or notes may be brought to light, for their historical value would be very great; probably, indeed, more than one page of history would have to be re-written were such neglected evidence (of which much must exist) laid before those who could make proper use of it.
} 
Captain Ferris had been sent back to Peshawar to bring up fresh supplies, and the force was, therefore, weakened by the strength of his escort. The operations were, however, successful, and the opposition of the enemy much less spirited than on the 22nd. A 6 -pounder of the Silk artillery was carried by an elephant, under Lieutenant Barr's direction, to the summit of a ridge, and fire from it was kept up at intervals throughout the day.

The force under Mackeson, who was assisted by Lieutenant Maule, advanced along another range, where it had some smart fighting. Eventually the camp of the main body was brought forward to ground below the village of Lal Chini, and Lieutenants Dowson and Rattray occupied the heights on either flank with small bodies of infantry. Mackeson also held the advanced position that he had taken up.

On the 25th July the heights immediately before Fort Ali Masjid were attacked, and as it was evident that the opposition would be strenuous, two companies of the Regular infantry and a large force 'of the Sikh troops under their brigadier, Shaikh Basawan, were employed in addition to the $A$ fghan levies.

Captain Farmer commanded the troops which acted with the Sikhs; and the combined force drove back the Afridi defenders from their original position to the summit of a lofty and precipitous hill, whence infantry fire failed to " slodge them.

The Khaibaris, inleed, made a bold counter-stroke, and descended from their breastwork with the intention of attacking Captain Farmer's left, but this attempt was frustrated by artillery fire, and the counterstroke defeated.

Colonel Wade then directed his guns on a cantonment occupied by the Afghan troops, and directed the Sikhs to charge the buildings, to plunder them, and to retreat to the shelter of his force, bringing their spoil with them.

This undertaking was, however, respectfully declined by the Sikhs, who explained that it was contrary to the traditions of their army to retire from any position that they had once taken up.

They were quite ready to advance and die if the Colonel desired it, but to retire was out of the question.

Fighting continued all day, without any material advantage to either side, and the losses were considerable, those of Colonel Wade's force amounting to about 180 killed and wounded during the four day's' operations.

When night fell, a party from the position commanded by Captain Farmer was silently pushed forward to rush the fort, but, to their surprise, found it vacated. Captain Ferris' force had also advanced, and was ready to join in the intended assault at daylight. The Afridi defenders of the Khaibar Pass had held their ground well against a determined and sustained attack, but they failed to deliver any effective counter-attack, though the advantage of position lay with them. It may be assumed that they were disheartened by the knowledge that Giazni had fallen, and that the Afghan troops under Akbar Khan had 
withdrawn from Jalalabad to Kabul. It must have been clear to them that the Royal cause was, for the moment at any rate, triumphant, and that it was high time to come to terms with the winning side.

Wade's force, much improved by its short and successful experience of hill fighting on scientific principles, now moved on by easy stages to Kabul. The Afghan levies were distributed along the road in suitable posts, it being considered undesirable to take them to the capital.

On September 3rd, Colonel Wade brought his mission to a successful close, as on that day Shahzada Timur entered Kabul. On the 5th of the following month the Sikh contingent began their return journey to India.

Lord Auckland, a warmly appreciative master, thus commented on the performance of Wade and his officers, in a private letter dated

"MY DeAr Sir,

$$
\text { "Simla, August 21st, } 1839 .
$$

"I have been greatly occupied of late, and you must not think because I have not written to you that I have not felt a warm interest in all your proceedings. I have rejoiced at your success as influencing that of the great enterprise in which we are engaged, and have rejoiced at it also on your own account. It realises the hope which I had encouraged that your position at Peshawar, though irksome and doubtful, and often discouraging, was one of real importance, and might bring honour to yourself and enable you to render real service to the State. I cannot but applaud the manner in which the defences and difficulties of the Pass have been mastered, and it will have a good effect that they have been mastered rather by lead and iron than by gold and silver. Your little band of British officers seem most admirably to have seconded you, and I shall presently have to ask you to present a sword in my name to your Sikh Colonel.

$$
\begin{aligned}
& \text { "Nost truly, dear Sir, } \\
& \text { "(Signed) Auckland." }
\end{aligned}
$$

Three months later, Colonel Wade received an intimation from Sir John Hobhouse that the Queen had been pleased to confer the honour of Knighthood upon him, and that he would also receive the Companionship of the Order of the Bath "in token of Her Majesty's approbation of his conduct and services during the late expedition in Afghanistan."

Unfortunately, Sir Claude Wade's despatch to the Governor-General, describing his operations in the Khaibar Pass, was never published. It is hard to say why this was so, but some unfriendly influence was presumably at work.

One thing is certain, that Wade's achievement, both from a military and a political point of view, failed to reccive due recognition. At the time of its performance public attention was concentrated on the movements of the "Army of the Indus," and the attention of historians has since been mainly devoted to greater and more dramatic episodes of the

1 This letter, with a mass of correspondence relating to Sir Claude Wade's diplcmatic career, is in possession of Mr. Claude F. Wade, his only son. 
TIE FIRST FORCING OF THE KHAIBAR PASS.

Afghan War. The capture of Ghanzi, the occupation of Kabul, the destruction of Elphinstone's army, the brilliant defence of Jalalabad, the advance from Peshawar of Sir George Pollock, the "retirement of General Nott from Kandahar by way of Kabul,"-all these stirring incidents fire the imagination of the writers and readers, and have thrown into the shade achierements that deserve to be remembered with admiration.

Thus it is that Sir Claude Wade's bold and hazardous opcrations - in the Khaibar have been robbed of the measure of fame that is their due. 